\title{
Leadership According to D Source in Deuteronomy 1:9-18
}

\author{
Jeane Marie Tulung ${ }^{1}$ Jenry Elrich Cornelis Mandey ${ }^{2}$ \\ ${ }^{1,2}$ Lecturer of STAKN Manado (State Christian Seminary in Manado)
}

\begin{abstract}
Leadership is an important aspect of human social life. It had appeared even in the ancient life of the Israelites. Deuteronomistic History (DH) is one of the historical writings in the Old Testament and even the longest one ever documented. Leadership and the role of the leaders are also written in $\mathrm{DH}$, moreover the role of the leaders become an important story in its material. Deut. 1:9-18 is also included. Through literary criticsm of the authorship of DH, this article aims to explain the leadership and the role of the leaders in accordance with DH particularly observed from the leaders explained in Deut. 1:9-18.
\end{abstract}

Keywords:- Deuteronomistic, Deuteronomy, D Source, Leadership

\section{INTRODUCTION}

Leadership is one of the important aspects in the social life of every human. Leadership had already emerged in the ancient world. And it is undoubtedly that the ancient world of Israel had also been familiar with a system that used the leadership along with its forms. The role of those who were given the responsibility to be an example and to lead the people indicates an interesting thing and also noble action.

The whole tradition of the ancient Israel recorded in the Bible even provide clues about the importance of being leaders. Whether in every role he does in particular as a "leader" as well as the duties and responsibilities as a person. We can see that the role of the characters in the Bible also indicates the leadership in the actions undertaken by each of these figures.

In particular, the part that widely discusses about the history of the kingdoms of Israel with its historical work is the D source which is the Deuteronomistic source. I especially want to observe that there is a role of the characters with their leadership mentioned with certain terms explaining the role of the leaders in the ancient Israel world with each of their roles.

Certainly the historical work of the D source, or which is known as the Deuteronomistic History is something very broad to be observed, then the certain part of this historical work will be focused to a passage in Deuteronomy 1:9-18 that tells about the appointment of the leaders and emphasised more on the leadership role of the judges which is seen as a form leadership.

\section{VOCABULARIES ABOUT LEADERSHIP}

The role of the leaders is always mentioned in the Old Testament which initiated any political action that affected the socio-religious aspect in time when those leaders were alive. The leaders that I mean here are actually not limited to political leaders only, although the role of the political leaders played the biggest role among the entire characters that can be classified as leaders.

I see from the perspective that all the figures that have a role to move the people, or, more broadly, to move the multitudes can be seen as a figure who has a leadership role. In English, the word "leader" has the root "lead" in which this word can also be a form of verb "to lead", "to guide", even "to train". While for the word "leaders" can be understood as a person who does the work to "lead". While in English as well, leadership is also the compound morphology of the same root, the leader, therefore the leadership cannot be separated from the leader itself. According to the Oxford Dictionary, the leader is "the person who leads, commands, or precedes a group, organization, or country" [1]. Then the "leadership" refers to the subject of "leader" and "the way of leading" [2].

In the Bible translation of TB-LAI there are words specifically translated as pemimpin or "leader", even to show that he becomes the leader with the leadership role, it is actually not limited to one form of such leader only. The translation of the word pemimpin in Indonesian (leader) from Hebrew used by TB-LAI in Enneateuch [3] are in

- Exodus 2:14 sar; 16:22 nasi'; 18:21, 25 sar; 34:31 nasi'; 35:27 nasi';

- Numbers 1:16,44 nasi'; 2:3,5,7,10,12,14,18,20,22,25,27,29 nasi'; 3:30,32,35 nasi'; 4:34,46 nasi'; 7:2,3,10,11,18,24,30,36,42,48,54,60,66,72,78,84 nasi'; 10:4 nasi'; 13:2 nasi'; 14:4 rosh; 16:2 nasi'; 17:2,6 nasi'; 25:14,18 nasi'; 27:2 nasi'; 31:13 nasi', 31:14,48 nasi'; 32:2 nasi'; 34:18,22,23,24,25,26,27,28 nasi'; $36: 1$ rosh 
- Deuteronomy 1:15 rosh;

- Joshua 9:15,18,19,21 nasi'; 17:4 nasi'; 22:14,30,32 nasi'

- Judges 5:15 sar; 10:18 sar

- 1 Samuel 22:12 sar; 3:38 sar; 23:19 sar

- 1 Kings 8:1 rosh; 9:23 sar; 14:27 sar; 11:14 sar

There are three vocabularies translated as "leaders" or pemimpin here in the Enneateuch, which are nasi', sar and rosh. The most used word here is the word nasi' which also can be translated as "prince" in the sense of "leader", but it does not mean that it is a "leader" in general, because this word appear the most in some parts of the book of Deuteronomy as mentioned above, while the book of Deuteronomy is also the book where the word "leader" appears in Indonesian and even in English. The word nasi' can be understood as "president" or "chief" in modern sense, which means the head in an organisation.

The vocabulary which is also used as the second most word here is sar. This word is actually quite hard to differentiate with the word nasi'. Nevertheless, the word nasi' apparently got a higher position in its connotation that sar, while sar is actually quite less common than nasi'.

While the word which is less translated as "leader" or pemimpin in Enneateuch is apparently the word rosh. This word rosh, however, is more common than the other two words before. The word rosh literally can be translated as "head" which means the leader who directs, acts as the head. This word rosh is as well appeared in the focus of discussion in this article in Deuteronomy 1:9-18.

Leaders and leadership, as described above, is not only limited to these three words, which are only able to be translated as "leader" in English or pemimpin in Indonesian The word "leader" as observed from its meaning, has actually broader sense than just nasi', sar or rosh. In the entire Old Testament as well, the types of leaders are pretty much shown through the role of leaders.

The historical book that is long enough to tell of the leadership characters is the Deuteronomistic History. This historical work also included the roles of many characters as the other leaders, which are not only limited to nasi', sar and rosh. Even the characters with their roles such as: Melech "king", Kohen "imam" and Nevi ' "prophet", are also adorn the stories of the characters in the Old Testament.

But important to note here is the role of rosh, are mentioned in section Deuteronomy 1: 9-18. This section is definitely the writings of the source D or Work History Deuteronomistic. For that, keep in mind what and how the background source D, both in its position as one of the sources who wrote Penta teuch, as well as in his position as Pe-history of the most great as Deuteronomistic historical works in the Tanakh.

But an important thing to note here is the role of rosh, which is mentioned in the passage of Deuteronomy 1:9-18. This passage is definitely the work of D source or the Deuteronomistic History. Therefore, it is necessary to look at what and how is the background of this D source, whether from its position as one of the authors of the Pentateuch, or in its position as the biggest history teller as the Deuteronomistic History in Tanakh or the Old Testament.

\section{D SOURCE AMONGST THE OTHER SOURCES}

The writing of the Pentateuch or traditionally known as the five "books of Moses" actually involves several diverse authors. The modern world does not view Moses as the sole author of these books, from Genesis to Deuteronomy. This opinion is primarily based on the assessment that there are some stories which are repeated with the same essence, among others, in the book of Genesis, where the creation story seems to have repetition by different authors between Genesis 1: 1-2:4a and Genesis 2:4b-24. Genesis 1:1-2:4a is the story of the work of $\mathrm{P}$ source and Genesis 2:4b-24 is the story of the work of $\mathrm{J}$ source[4][5]. However, the example like this is just a small sample of suspicion about the different author in the Pentateuch indicated that Moses was not the author of these five books at all.

There are four main sources involved in the writing of the books in Pentateuch, based on the observation of the repeated stories, or the similar stories with the different language style, and some little difference seen in these stories, which are in: Genesis 2:4b-24 and Genesis 1:1-2:4a; there is even a story that is repeated three times, i.e. in Gen. 12:10-20, 20:1-18 and 26:1-11 [6][7].

The four main sources include: J source, E source, D source, and P source. Those sources can be briefly described as follows:

- J source: The Jahwist source who mentions the name of the Lord with YHWH/Yahweh. Written in ca. 900$800 \mathrm{BC}$ in the Kingdom of Judah.

- E source: The Elohist source who mentions the name of the Lord with Elohim. Written in ca. 800-700 BC in the Northern Kingdom of Israel

- D source: The Deuteronomist source. Becomes the author of the book of Deuteronomy. Emerged in ca. 622 $\mathrm{BC}$ in Jerusalem when the Temple was being reconstructed under the rule of King Josiah. In that moment, the workers who was reconstructing the Temple found a scroll which was seen as the Torah. (Cp. 2 Kings 22:8) 
- P source: sumber Priester Codex merupakan sumber yang ditulis oleh para imam dengan banyak menonjolkan peranan kultis dalam Taurat. Sumber ini ditulis pada sekitaran tahun 550-500 SM pada masa pembuangan ke Babel.

- Priester Codex source, written by the priests with the emphasis of the cultic role in the Torah. This source was written in ca. 550-500 BC in the exilic period in Babylonia [5][6].

Our focus here is regarding the D source. D source actually cannot be classified as a single author, but rather as a Deuteronomistic school or as a movement [8]. In general, the Deuteronomistic materials are contained in the book of Deuteronomy, Joshua, Judges, $1 \& 2$ Samuel, and $1 \& 2$ Kings, and partly in the book of Jeremiah (Jer. $30-35 ; 46-52)[3]$.

It is commonly agreed that the D source is a separate work from the book of Tetrateuch (GenesisNumbers) and the Chronicler's History (1\&2 Chronicles and Ezra-Nehemiah) whose sources include J, E, and $\mathrm{P}$, thus some scholars classify the editing Tetrateuch as well as the Deuteronomistic Jeremiah was during the exile in Babylon (ca. 6th century BC)[9]. In this century certainly, the historical work recorded by the D source began to emerge.

Thus it can be seen that the D source did not only emerge as one of the authors of the Pentateuch which is the five "book of Moses", but the D source also produced a work which scholars can categorise it as a Deuteronomistic History. More about the Deuteronomistic History let us see the next part below.

\section{D SOURCE AS HISTORICAL WORK (DEUTERONOMISTIC HISTORY)}

As mentioned above, the D source is also known as the Deuteronomistic History. The name Deuteronomistic History (DH) is derived from German term, Deuteronomistiches Geschichtswerk (DtrG). The term was first used by Martin Noth in 1943 in his book: ÜberliferungsgeschichtlicheStudien[10]. The DH actually first emerged in ca. 600s BC at the time of the reformation of Hezekiah and the succeeded by the reformation of Josiah[3][5]. According to Bloemandaal, the reformation undertaken with the characterisation of the Deuteronomistic reform is also known as the Josiah reformation, which occurred in $622 \mathrm{BC}[5]$. Santoso, however, uses the dating of this work in ca. $550 \mathrm{BC}$, based on the idea that this historical work would later intensively be redacted at the exilic period, even it effected up to the post-exilic period, therefore it involves a long process[3].

It should be noted that this historical work resulted the book of Deuteronomy (Deuteronomium) as the charter documents of those reforms undertaken by Josiah[11]. The Book of Joshua also becomes part of this historical work and eventually formed a Hexateuch, the Pentateuch arrangement with the book of Joshua. DH also redacted the results of unification work of $\mathrm{J}$ and $\mathrm{E}$ to provide additions to them. The other three books which also as the work of DH are Judges, $1 \& 2$ Samuel and $1 \& 2$ Kings. The third part is still separated from Hexateuch because apparently Hexateuch was not completed yet[3].

The most apparent in the theological perspective of DH is about God's call for Israel to be His chosen nation. The election of Israel isvery prominent in the theology of DH, even the Temple in Jerusalem and the city of Jerusalem is also of great concern in the DH[5].

Santoso explains the theology of DH concisely yet detailed[3], which are:

- Strictly mentioned that God loves the patriarchs of Israel: Abraham, Isaac and Jacob (eg Deuteronomy 10:15)

- God has chosen the patriarchs and their descendants (e.g. Deuteronomy 10:15; 12: 5; 17:15; 18: 5). The

"election" is understood as "the foundation of the love of God", and the "liberation of slavery".

- D source emphasising the "love of God"

- The people of God as a "brotherhood"

- Canaan becomes the place that God had promised to Israel, which thus belong to Israel, because the legitimacy of God: and specifically the land of Canaan is called: "a good land and a large" (Ex 3:8) or "land flowing with milk and honey "(Deuteronomy 6:3; 11:9)

- Freedom to take a "decision" lies in the people of Israel, whether to obey God or not. And it also has two consequences: "Bless" and "Curse". The person who does the command is the one who "does good in the eyes of God", whereas the one that does not is the one "who does evil in the sight of God".

- "Repentance" is a way out for those who have "done evil in the eyes of God".

\section{LEADERSHIP IN DEUTERONOMY 1:9-18}

The book of Deuteronomy with its part in chapter 1:9-18 certainly is a part of Deuteronomistic History (DH). This is undisputable that the book of Deuteronomy (Deuteronomium) is a result of the work of DH that first appears in Tanakh/Old Testament, moreover it is part of the Pentateuch. The importance of this part is to emphasise the diverse leadership. Not only the three types of "leadership" that often appear in the translated 
word "leader" in the Enneateuch by the TB-LAI and even the KJV, which are nasi', sar and rosh here - even though nasi' does not emerge here - but also emerge some sort of the other "leaders", with a different scope.

If we read this passage, we can see that this passage is included in the part of the first chapter about the story of Israel's journey from the other side of Jordan. This journey is a process of the Israelites entering the land of Canaan, therefore in the middle of the journey, apparently the burden of leadership that had to be faced by Moses needs to get help from the leaders as his subordinates in facing the smaller groups

Moses' leadership in this story is a model of the leadership in ancient Israel which also had known the form of organisation in organising the smaller groups of the entire Israel. Here the leadership is needed from the heads in charge of the tribes. Even the most important part described in this passage is the appointment of the "judges" in taking decisions and to hear the case. But it is certain that the explanation about the types of leader in this part is not only limited to one sort of leader.

To see some of the types of leader, here we need to identify a few keywords that indicate leadership in this passage in several verses.

- Ay. $13 \rightarrow$ wise men - hachamim; understanding (men) - nevonim; known (men) - yedhu'im; your heads rashechem

- Ay. $15 \rightarrow$ chief/head of the tribes - rashe-shivtechem; wise (men) - hachamim; known (men)- yedhu'im; heads - roshim; captains - sar; officers - shoterim

- Ay. $16 \rightarrow$ your judges - shoftechem

Here we can see that there is some kind of "positions" that must be executed. Those "positions" are: hachamim (vv. 14,15), nevonim (v. 14), yedhu'im (vv. 14,15), rosh (vv. 13, 15 2x), sar (v. 15), shoter (v. 15) and shofet (v. 16).

Hachamim is a term that refers to the characteristics of men, which is hacham that means wise, therefore the word hachamim refers to the wise men. This is also equal to the words nevonim and yedhu'im which mean the people who have understandings and knowledge/experinces, from the words biyn and yadha'. These three words are actually not quite exactly to be refered as "position" because this three things are competence or criteria needed to be achieved in order to have the position as the appointed leader.

One term that appears several times is rosh. This form of leadership position appears only once in verse 13 and twice in verse 15. In verse 13 TB-LAI clearly translates it as kepala or "head". While the KJV translates it as "rulers". But the "rulers" seems to reign in its nature, while kepala or "head" follows the literal meaning as "head". This form shows the type of leadership which is common That is as the head of smaller groups of the entire Israel under the leadership of Moses. Leaders should be the head, thinkers and movers of group or organisation. In verse 15, the word rosh emerged with form as rashe-shivtechem i.e. more specifically as "chief" who is the leader of each tribe of Israel. The second form of rosh appear with its plural form, which is roshim, it means "the heads", while TB-LAI is too general to translate it as pemimpin or "leader", while KJV is more literal to translate it with "head".

After rosh there emerge another type of leadership which is termed with sar. This word in verse 15 is translated as "captain" in KJV, while in NIV there translated as "commanders", apparently it is equal to the translation of TB-LAI which is kepala pasukan or the "head of the troops". Therefore the leadership of sar is also included the leadership in military. Thus shoter as well indicated the form of leadership in military. Literally it means as the "officers". KJV and NIV translate it with a similar form, which are "officers" and "officials", therefore TB-LAI translates it as pengatur pasukan or the "officers of the troops". Shoter apparently has to do with the military administration. Therefore the appointment of the leaders in verse 15 also includes the military administration not only the leader of the troops.

The last position mentioned in this section is shofet. This word is mentioned in plural form, it means that the judge there was not the only one. Shofet quite takes a lot of attention even in the form of duties, it is also described there about how "to judge righteously" (v. 16) and "shall not respect persons in judgment" (v. 17). Shofet is derived from the word shafat, which means to judge. It means that the duty of shofet (judge) is to shafat (judge).

\section{CONCLUSION}

Leadership is the most important aspect of the success of an organisation in one group. Without leadership there will be no order in the social life of the community, even in the smallest organisation whatsoever. As the Bible says, "Where no counsel (or leader) is, the people fall: but in the multitude of counsellors there is safety." (Proverbs 11:14). Because of the leadership that the Israelite could endure in facing every struggle of the nation, and because of the leadership that we can read the stories in the Bible which are filled with stories of leaders.

The D source as the history teller that produced the most work in the Old Testament, also gives much informations about the leadership in the Bible. Especially found in Deuteronomy 1:9-18, it tells about the appointment of the leaders which also had some roles. Leadership in the ancient world of Israel indeed had some 
roles or positions, however in Deuteronomy 1:9-18 gives us at least a few forms, which are: head, commanders, officers and judge. Apparently, the leadership here indicates an independence of the Israelites, because the also had to choose their own leaders[4]. They were then given some criteria to choose the leaders, which: have to be wise, to have understandings/knowledge and even experience. Therefore, to elect a leader, in any kind of leader, there has to be good criteria. Leadership is not only being ruler, but has to be head, thus the main duty is to bring the subordinates to be directed.

\section{ABBREVIATIONS}

JSOT : Journal for the Study of the Old Testament

KJV : King James Version

NIV : New Internation Version

TB-LAI : Terjemahan Baru - Lembaga Alkitab Indonesia

\section{BIBLIOGRAPHY}

[1] Anonymous. 2010. "leader" in Oxford Dictionary. Oxford: Oxford University Press.

[2] Anonymous. 2010. "pimpin" in Kamus Besar Bahasa Indonesia. Jakarta: Balai Pustaka.

[3] Santoso, A. 2014.Satu Iota Tak Akan Ditiadakan.Cipanas: STT Cipanas Press, pp. 84-90.

[4] Dianne Bergant, Robert J. Karris (Eds.). 2002.Tafsir Alkitab Perjanjian Lama. Yogyakarta: Kanisius, pp. 34-38;

[5] J. Bloemendaal, Pengantar kepada Perjanjian Lama (Jakarta: BPK Gunung Mulia, 1980), 26

[6] Jenry E.C. Mandey, Studi Eksegese Historis Etimologis tentang Nama-nama dalam Kejadian 5, (Manado: Bachelor Thesis in STAKN Manado, 2014), 17-18;

[7] Barnabas Ludji, Pemahaman Dasar Perjanjian Lama jilid 1, (Bandung: Bina Media Informasi, 2009 ), 45.

[8] Rainer Albertz, "The riddle of the Deuteronomists" dalam Thomas Römer, The Future of the Deuteronomistic History, (Leuven: Leuven University Press, 2000), 2-4.

[9] Douglas A. Knight, 1995. "Deuteronomy and the Deuteronomists" dalam James Luther Mays, David L. Petersen, Kent Harold Richards, Old Testament Interpretation. Edinburgh:T\&T Clark, pp. 65-66

[10] Thomas Römer dan Jean-Daniel Macchi, 2000. Israel Constructs Its History: Deuteronomistic Historiography in Recent Research, JSOT (Sheffield: Sheffield Academic Press, pp. 24

[11] Norman K. Gottwald, 1987. The Hebrew Bible (Philadelphia: Fortress Press, pp. 139 